\title{
QUANTIFICATION OF SELECTED TRACE AND MINERAL ELEMENTS IN ROYAL JELLY FROM BULGARIA BY ICP-OES AND ETAAS
}

\author{
Ralitsa Balkanska ${ }^{1}$ \\ Elisaveta Mladenova ${ }^{2 *}$ \\ Irina Karadjova² \\ 'Institute of Animal Science \\ 2Sofia University "St. Kl. Ohridski", Faculty of Chemistry and Pharmacy \\ *corresponding author: elimladenova@chem.uni-sofia.bg \\ Received: 28 February 2017; accepted: 27 October, 2017
}

\begin{abstract}
The objective of the present study was to investigate selected trace and mineral elements in Royal Jelly (RJ) from Bulgaria. A total of $30 \mathrm{RJ}$ samples were included in the study. The analytical procedure consisted of the microwave digestion of the RJ samples with nitric acid followed by instrumental measurement. Concentrations of $\mathrm{Al}, \mathrm{Ba}, \mathrm{Ca}, \mathrm{Cr}$, $\mathrm{Cu}, \mathrm{Fe}, \mathrm{K}, \mathrm{Mg}, \mathrm{Mn}, \mathrm{Na}, \mathrm{P}, \mathrm{Sr}$ and $\mathrm{Zn}$ were determined using inductively coupled plasma optical emission spectroscopy (ICP-OES), while As, Cd, Co, Ni and Pb were determined by electrothermal atomic absorption spectrometry (ETAAS). Our results showed that elements $\mathrm{K}, \mathrm{Mg}$, Ca represented $96 \%$ from the total mineral content of the RJ samples from Bulgaria, while the most abundant trace element was $\mathrm{Na}$, followed by $\mathrm{Zn}$. The elements $\mathrm{Ba}, \mathrm{Cr}, \mathrm{Cu}, \mathrm{Fe}, \mathrm{Mn}$ and $\mathrm{Sr}$ were found in trace concentration levels and elements $\mathrm{As}, \mathrm{Pb}$, $\mathrm{Cd}, \mathrm{Co}$ and $\mathrm{Ni}$ in microconcentration levels. Selected mineral and trace elements were found in relatively constant concentration levels in all of the analyzed RJ samples. It was concluded that chemical element content did not depend on geographical origin and was under homeostatic adjustment in RJs.
\end{abstract}

Keywords: Bulgaria, ETAAS, ICP-OES, mineral elements, royal jelly, trace elements

\section{INTRODUCTION}

Royal jelly (RJ) is a product secreted from the hypopharyngeal and mandibular glands of young worker honeybees (Apis mellifera) and serves as food for the bee queen and the larvae up to three days old. The composition of RJ has been studied by several authors, but data available in the literature are inadequate and unstructured with considerable variety. This is probably due to the variability of the product itself and to the different methods used for its analysis. RJ is mainly composed of water (60-70\%), proteins (9-18\%), carbohydrates (7-18\%), lipids (3-8\%), amino acids, vitamins and minerals. In fresh R], the mineral content varies between $0.8 \%$ and 3\% (Sabatini et al., 2009). Royal jelly typically is contaminated by pollen grains (Ricciardelli d'Albore \& Battaglini Bernardini, 1978; Piana et al., 2006).

Royal Jelly is a natural food product widely used in diets and cosmetics. This elemental analysis of
$\mathrm{RJ}$ is of great interest from a nutritional and toxicological point of view and requires food quality control (Chen \& Chen, 1995). The biological activities of RJs are variable and have been correlated to the content of trace elements. Researchers believe that the health benefits are attributed to such various ingredients present in RJs as B-complex vitamins, fatty acids and trace elements (Kim \& Lee, 2010). While being a natural source of essential elements for consumers, RJ could also contain $\mathrm{As}, \mathrm{Cd}, \mathrm{Cr}, \mathrm{Ni}$ and $\mathrm{Pb}$ which are harmful to human health. These elements may exist in $\mathrm{RJ}$ as free metal ions, as small labile complexes or as complexes with RJ proteins and other macromolecules. Previous studies by Serra Bonhevi (1991) and Nation \& Robinson (1971) on the content of trace and mineral elements in RJ were very limited. In a study on the mineral content by Stocker et al. (2005) was determined the concentrations of 28 trace elements in acid digested RJ samples from various botanical, geographical and geological origins. At present there 
is an international standard which specifies the production and sanitary requirements for royal jelly and establishes a series of organoleptic and chemical test methods to control its quality (ISO/ DIS 12824:2016), there is no information about trace and mineral element content.

The elemental analysis of RJs from different geographical regions is important both to define the content of essential elements, which ensures health benefits as well as to confirm the potential absence of toxic elements, which could adversely affect humans. Results from systematic investigations on mineral content of royal jellies from Bulgaria have not been presented and published until now.

The purpose of the present study was the quantification of major and trace chemical elements in samples of RJ with a geographical indication from Bulgaria. The analyses were focused on the determination of such essential elements as $\mathrm{Ca}, \mathrm{Co}, \mathrm{Fe}, \mathrm{K}, \mathrm{Mg}, \mathrm{Na}, \mathrm{P}$ and $\mathrm{Zn}$ and such toxic elements as As, Cd, Ni and Pb. Results obtained will be discussed in based on the suggestion that RJ is a form of insect lactation level and shows homeostatic control of chemical element content.

\section{MATERIAL AND METHODS}

\section{Samples}

The present study was conducted using thirty representative RJ samples with guaranteed origin. Most of the samples were collected from private beekeepers from different regions of Bulgaria: ten samples from the western region around the city of Sofia, seven samples from the eastern Black sea region around the city of Varna and seven samples from the mountain region around city of Lovech. Six other samples came from the market but their geographical origin was known to be from northern Bulgaria: three RJ samples from the region of the city of Veliko Tarnovo and three RJ samples from the region of city of Razgrad (see Fig. 1). The amount of each RJ sample was around $20 \mathrm{~g}$. All samples were collected using the artificial cups method according to Grout (1992). The samples were stored in dark glass containers and kept at $-20^{\circ} \mathrm{C}$ until analysis. All measurements were performed in 2014.

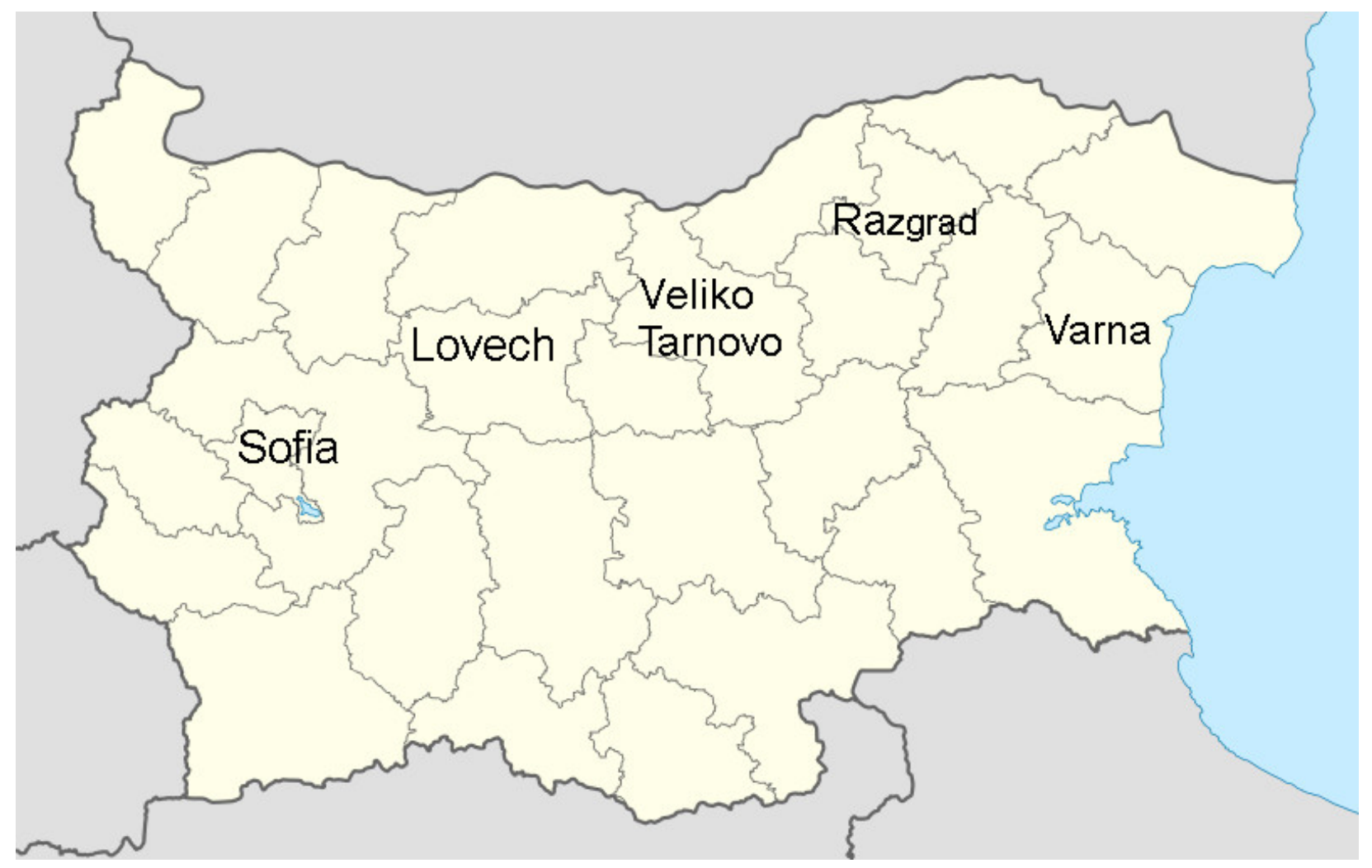

Fig. 1. Map of RJ sampling localities in Bulgaria. 


\section{Reagents}

All reagents were of analytical-reagent grade and allaqueous solutions were prepared with MilliQ water (MilliporeCorp., Milford, MA, USA). The stock standard solutions were Certipur ICP Multi-element standard solution IV (23 elements in diluted nitric acid), Merck Millipore, $1000 \mathrm{mg} / \mathrm{L}$ and Certipur Reference material GF AAS Multi Element Standard solution XVIII, Merck Millipore, $100 \mathrm{mg} / \mathrm{L}$. The working standard solutions were prepared weekly through appropriate dilutions. Concentrated $\mathrm{HNO}_{3}$ (65\%, suprapure, Merck) was used for RJ wet digestion. A stock standard solution of $\mathrm{Pd} 250 \mu \mathrm{g} / \mathrm{mL}$ in $5 \% \mathrm{v} / \mathrm{v} \mathrm{HCl}$ was injected $(10 \mu \mathrm{L})$ into the graphite furnace to obtain permanent modifier coatings.

\section{Procedures for sample preparation}

An accurately weighed RJ sample (0.5 g) was placed in PTFE vessels of a microwave digestion system and $5 \mathrm{~mL}$ concentrated $\mathrm{HNO}_{3}$ was added. The vessels were capped closed, tightened and placed in the rotor of a microwave oven. The digestion was carried out following the program - 200W/5min; 0W/5min; 500W/5min. The vessels were cooled down to the room temperature. Samples were quantitatively transferred into calibrated volumetric flasks and made up to $25 \mathrm{~mL}$ with MilliQ water. Blank samples were passed through the whole procedure.

\section{Instruments}

Inductively coupled plasma optical emission spectrometry (ICP-OES) was used for the determination of $\mathrm{Al}, \mathrm{Ba}, \mathrm{Ca}, \mathrm{Cr}, \mathrm{Cu}, \mathrm{Fe}, \mathrm{K}, \mathrm{Mg}, \mathrm{Mn}$, $\mathrm{Na}, \mathrm{P}, \mathrm{Sr}$ and $\mathrm{Zn}$ in acid digested $\mathrm{RJ}$ samples. The ICP-OES measurements were carried out with inductively coupled plasma optical emission spectrometer (ICP-OES) (Jobin Yvon, Ultima 2). The optimized instrumental parameters are presented in Tab. S1 (Supplementary materials). Calibration against standard calibration curve prepared with aqueous standard solution is recommended.

Electrothermal atomic absorption spectrometry (ETAAS) was used for the determination of toxic element ( $\mathrm{As}, \mathrm{Cd}, \mathrm{Co}, \mathrm{Ni}$ and $\mathrm{Pb}$ ) content in $\mathrm{RJ}$ samples without preliminary sample digestion.
Electrothermal atomic absorption measurements were carried out on a Perkin-Elmer (Norwalk, CT, USA) Zeeman 3030 spectrometer with an HGA-600 graphite furnace. The light sources were hollow cathode lamps for $\mathrm{Co}, \mathrm{Ni}$ and $\mathrm{Pb}$ and an electrodeless discharge lamp for As and $\mathrm{Cd}$. The spectral bandpass for all analytes was $0.7 \mathrm{~nm}$. Pyrolytic graphite-coated tubes with pyrocoated platforms were used as atomizers. Sample aliquots of $20 \mu \mathrm{L}$ were injected into the graphite furnace using autosampler AS-70. All measurements were carried out with at least three replicates and values measured were based on integrated absorbance. Pretreatment and atomization curves, prepared for $\mathrm{Cd}$ and $\mathrm{Pb}$, showed that ETAAS measurement of $\mathrm{Pb}$ was possible without a modifier with the use of loss-free pretreatment at $450^{\circ} \mathrm{C}$. ETAAS measurement of As and Cd were performed in the presence of $10 \mu \mathrm{L} 250 \mu \mathrm{g} / \mathrm{mL}$ Pd solution with the use of $900^{\circ} \mathrm{C}(\mathrm{As})$ and $600^{\circ} \mathrm{C}(\mathrm{Cd})$ as loss-free pretreatment temperatures. Optimal instrumental parameters for direct ETAAS measurements of $\mathrm{As}, \mathrm{Cd}, \mathrm{Ni}$ and $\mathrm{Pb}$ are summarized in Tab. S2 and Tab.S3 (see Supplementary material). Matrix interferences evaluated through the ratio of the slopes of calibration curves obtained in the presence of $2 \%(\mathrm{w} / \mathrm{v})$ royal jelly solution in 0.1 $\mathrm{mol} / \mathrm{L} \mathrm{HNO}_{3}$ and for aqueous standards calls for standard addition method for calibration.

\section{Statistical analysis}

Each sample was analyzed in triplicates and a calculated mean was used for statistical treatment. Univariate analysis, which involves description of the distribution of each element in sample set as central tendency (including the mean, median, and mode) and results dispersion as the range and quartiles of the data-set as well as measures of spread such as the variance and standard deviation) was performed. The shape of the distribution was defined via such indices as skewness and kurtosis. Characteristics of a variable's distribution were depicted in graphical form through box plotes. Data was performed using the SPSS Statistical Package, version 21 for Windows (IBM Corp.). 
Table 1

Concentrations of mineral elements $(\mathrm{mg} / \mathrm{kg})$ in RJ samples (three parallel analyses of each sample) from Bulgaria: calculated values for central tendencies represented as mean and median; dispersion of results represented as standard deviation; median relative standard deviation; minimal and maximal values; kurtosis as characteristic of extreme deviations from the mean value; and skewness as characteristic of population asymmetry

\begin{tabular}{ccccccccc}
\hline Element, & Mean & Median & $\begin{array}{c}\text { Standard } \\
\text { deviation, SD }\end{array}$ & $\begin{array}{c}\text { RSD }^{*}, \\
\%\end{array}$ & $\begin{array}{c}\text { Min } \\
\text { value }\end{array}$ & $\begin{array}{c}\text { Max } \\
\text { value }\end{array}$ & Kurtosis & Skewness \\
\hline $\mathrm{Al}$ & 3.0 & 2.75 & 1.37 & 46 & 1.67 & 7.9 & 1.16 & 0.2 \\
$\mathrm{As}$ & 0.025 & 0.023 & 0.014 & 56 & 0.011 & 0.074 & 1.52 & 1.64 \\
$\mathrm{Ba}$ & 0.36 & 0.33 & 0.13 & 56 & 0.17 & 0.60 & -1.38 & 0.12 \\
$\mathrm{Ca}$ & 153 & 156 & 9 & 6 & 139 & 163 & -1.15 & -0.49 \\
$\mathrm{Cd}$ & 0.003 & 0.003 & 0.002 & 67 & 0.001 & 0.006 & 0.56 & 1.28 \\
$\mathrm{Co}$ & 0.007 & 0.007 & 0.002 & 29 & 0.003 & 0.010 & 0.204 & 0.65 \\
$\mathrm{Cr}$ & 0.68 & 0.42 & 0.62 & 91 & 0.20 & 2.3 & -1.59 & 0.63 \\
$\mathrm{Cu}$ & 4.4 & 4.4 & 0.3 & 6 & 4.0 & 4.9 & -1.54 & 0.12 \\
$\mathrm{Fe}$ & 17 & 17 & 2.5 & 15 & 12 & 21 & -0.84 & 0.069 \\
$\mathrm{~K}$ & 2031 & 2015 & 48 & 2 & 1978 & 2102 & -1.6 & 0.41 \\
$\mathrm{Mg}$ & 259 & 262 & 11 & 4 & 241 & 273 & -0.82 & -0.43 \\
$\mathrm{Mn}$ & 1.12 & 1.26 & 0.44 & 39 & 0.34 & 1.69 & -1.25 & -0.18 \\
$\mathrm{Mo}$ & 0.14 & 0.14 & 0.02 & 14 & 0.10 & 0.16 & -1.65 & -0.89 \\
$\mathrm{Na}$ & 95 & 95 & 2 & 2 & 91 & 98 & -0.38 & -0.35 \\
$\mathrm{Ni}$ & 0.068 & 0.069 & 0.017 & 25 & 0.035 & 0.094 & -0.77 & 0.46 \\
$\mathrm{P}$ & 2009 & 2007 & 39 & 2 & 1927 & 2096 & -1.63 & -0.06 \\
$\mathrm{~Pb}$ & 0.15 & 0.07 & 0.28 & 187 & 0.02 & 0.98 & 3.53 & 1.87 \\
$\mathrm{Se}$ & 0.41 & 0.48 & 0.16 & 39 & 0.04 & 0.53 & -1.89 & -0.76 \\
$\mathrm{Sr}$ & 0.36 & 0.35 & 0.14 & 39 & 0.19 & 0.62 & -1.19 & 0.13 \\
$\mathrm{~V}$ & 0.013 & 0.013 & 0.005 & 38 & 0.007 & 0.029 & -1.79 & -0.56 \\
$\mathrm{Zn}$ & 21 & 21 & 2 & 10 & 19 & 29 & 1.07 & 0.98 \\
\hline & & & & & & & & \\
\hline
\end{tabular}

*Relative standard deviation, represented as Mean/SD*100

\section{Results}

The results obtained for all studied elements from the analysis of $30 \mathrm{RJs}$ are summarized in Tab. 1 with the use of descriptive statistics.

The most abundant elements in all the $\mathrm{RJ}$ samples were $\mathrm{K}, \mathrm{P}, \mathrm{Mg}, \mathrm{Ca}$ and $\mathrm{Na}$ with average concentrations of $2031 \mathrm{mg} / \mathrm{kg}, 2009 \mathrm{mg} / \mathrm{kg}, 259$ $\mathrm{mg} / \mathrm{kg}, 153 \mathrm{mg} / \mathrm{kg}$, and $95 \mathrm{mg} / \mathrm{kg}$, respectively. Moreover, their concentrations in all studied RJ samples were quite similar and very close to the mean value (Relative Standard Deviation, RSD is between 1 and $5 \%$ ). The skewness values were fairly symmetrically distributed from -0.35 (Na) to $0.41(K)$. The percentage distribution of major elements as well as box plots diagrams for $\mathrm{Ca}$, $\mathrm{Ma}$ and $\mathrm{Na}$ are depicted at Fig. 2 and Fig. 3 respectively.

The other elements were presented at lower concentration levels as trace elements. The RSD values for essential elements $\mathrm{Cu}, \mathrm{Fe}, \mathrm{Mo}$ and $\mathrm{Zn}$ were below $15 \%$ with the skewness values were moderately skewed below 1 . The concentration levels of toxic elements $\mathrm{As}, \mathrm{Cd}, \mathrm{Ni}$ and $\mathrm{Pb}$ broadly varied, although for all RJs they were below permissible limits for honey. The data are quite asymmetrically distributed and 


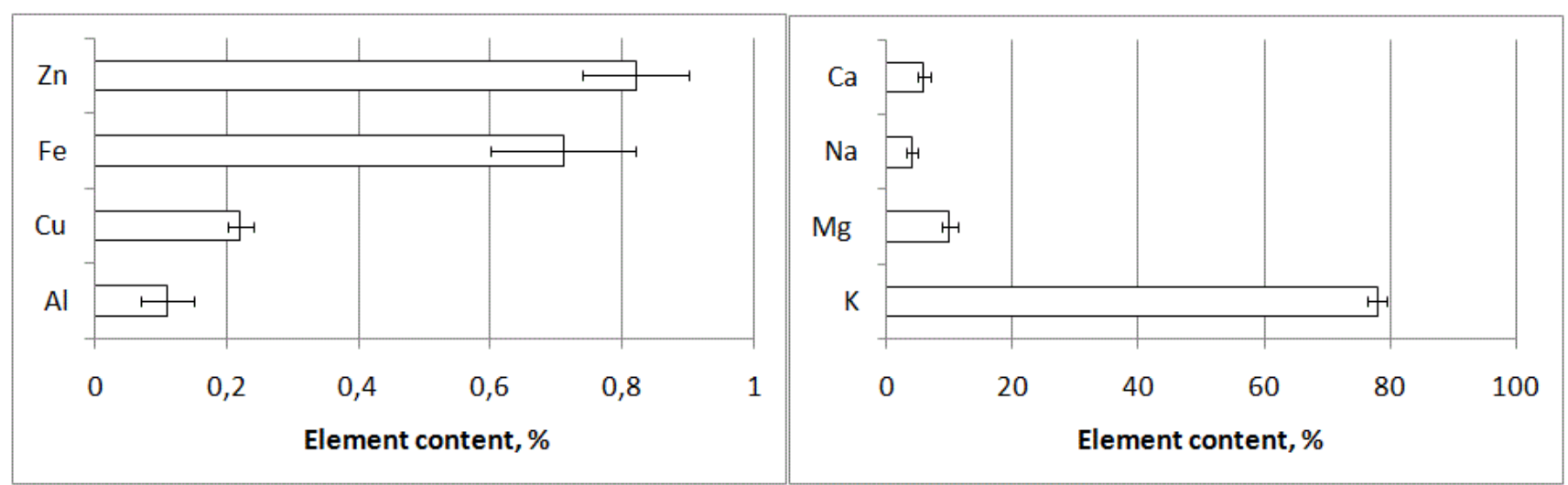

Fig. 2. Major element content (\%) in RJ samples from Bulgaria.

heavily tailored, with extreme deviation from the mean, which means the serious influence of external factors. Evidently the content of these elements is not under homeostatic control.

\section{DISCUSSION}

Regardless of origin, potassium (K) occurred at the highest concentration level and represented $78 \%$ of the total mineral content determined in the samples (Fig. 2). Magnesium (Mg) was the second largest with respect to content level (10\%) followed by Ca (6\%) and $\mathrm{Na}(3.7 \%)$. The elements $\mathrm{Zn}$ and Fe were determined as less than $1 \%$. Potassium is known to be the most abundant element in honey and bee pollen which are precursors for RJ (Stocker et al.,

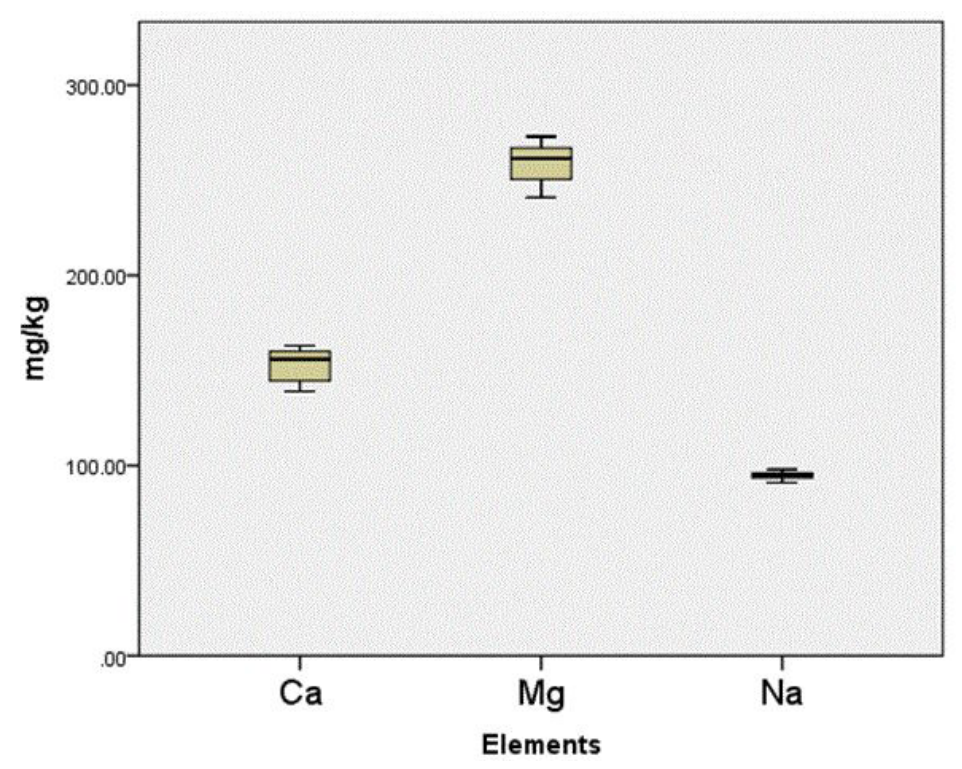

Fig. 3. Box plot diagram of the elements $\mathrm{Ca}, \mathrm{Mg}$ and $\mathrm{Na}$ in RJ samples from Bulgaria. For each element minimum, maximum and median values are shown.
2005; Terrab et al., 2005; Szczęsna, 2007) and was also found at very high concentrations of $11180 \mathrm{mg} / \mathrm{kg}$ in bee tissue (Kump, Necemer, \& Šnajder, 1996). However, K levels in all these matrices widely varied depending on the geographical region. In addition, the levels in honey and pollens depended on their botanical origin but the ones in all studied RJs from the present study were almost constant and only slightly varied, independently from geographical region or botanical origin which is consistent with conclusions by Stocker et al. (2005).

The same conclusion was valid for $P$ content in studied RJ samples, whose values ranged from $1927 \mathrm{mg} / \mathrm{kg}$ to $2096 \mathrm{mg} / \mathrm{kg}$ (Tab. 1) independently from geographical origin or botanical origin. It was confirmed in the present study that concentrations of essential elements $\mathrm{K}, \mathrm{Na}, \mathrm{P}, \mathrm{Ca}, \mathrm{Mg}$ which are important for bee-larvae growth were almost constant and evidently under homeostatic control. This conclusion is visualized in Fig. 3 representing box plots diagrams for $\mathrm{Ca}, \mathrm{Mg}$ and Na.

Considering the almost constant concentration levels of elements K, Na, Ca and Mg, the average ratios $\mathrm{K} / \mathrm{Na}$ and $\mathrm{Mg} / \mathrm{Ca}$, characterizing Bulgarian RJs, are calculated. The average K/Na ratios varied between 20.6 and 22.8 and were very close to the ratios reported by Stocker et al. (2005). The $\mathrm{Mg} / \mathrm{Ca}$ ratios had a relatively small range - from 1.5 to 1.9 and are a bit lower than these declared by Stocker et al. (2005). This decrease in Mg/Ca ratios could be explained with how soil properties 


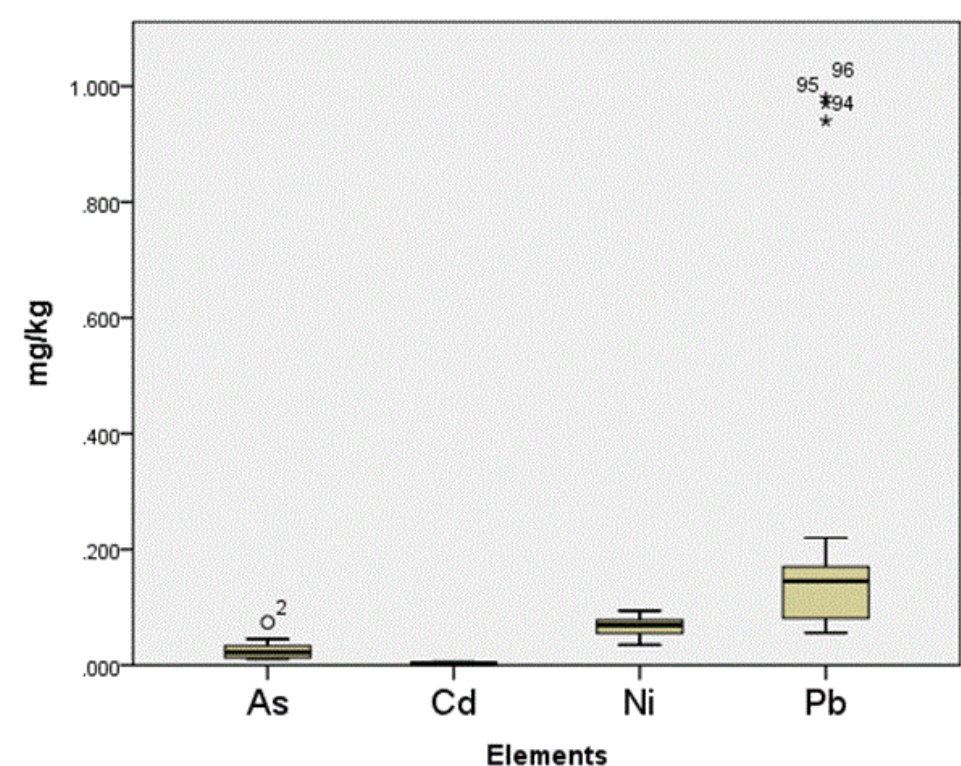

Fig. 4. Box plot diagram of the elements $\mathrm{As}, \mathrm{Cd}, \mathrm{Ni}$ and $\mathrm{Pb}$ in RJ samples from Bulgaria. For each element minimum, maximum and median values are shown.

influence the bioavailability of both elements to plants in Bulgaria. Stocker et al. (2005) stated that $\mathrm{K} / \mathrm{Na}$ ratios were more dependent on seasonal and geographical variation than the $\mathrm{Mg} / \mathrm{Ca}$ ratios.

The elemental analysis of different RJs from Bulgaria did not show a strong correlation between mineral elements' concentration and respective geographical region. Ivanov \& Chervenakova (1985) from Bulgaria found higher average values for $\mathrm{K}$ and $\mathrm{Zn}$ and lower values for $\mathrm{Ca}, \mathrm{Fe}$ and $\mathrm{Cu}$ in comparison to values reported by Serra Bonhevi, Spain (1991). The differences between these elements were not more than $5.5 \mu$ gith the exception of K. Mureșan et al. (2016) reported similar results to ours for Ca, Fe and $\mathrm{Cu}$ concentrations in $\mathrm{RJ}$, and again $\mathrm{K}, \mathrm{Mg}$ and Ca were the predominant mineral elements.

The results obtained for other trace elements $\mathrm{Al}, \mathrm{Ba}, \mathrm{Co}, \mathrm{Cr}, \mathrm{Cu}, \mathrm{Fe}, \mathrm{Mn}, \mathrm{Sr}$ and $\mathrm{Zn}$ found in $\mathrm{RJ}$ samples showed a wider range of variations (see Tab. S1, Fig. S1 in Supplementary material). The wide range in the content of essential elements $\mathrm{Fe}, \mathrm{Cu}$ and $\mathrm{Zn}$ suggested stronger correlation with the geographical origin of RJ. The variations in the concentrations of elements $\mathrm{Al}, \mathrm{Mn}, \mathrm{Cr}, \mathrm{Sr}$ was due the result of exogenous contamination with dust aerosol as reported by Stocker et al. (2005). Evidently the content of trace elements was affected by the seasonal or geographical origin of the samples from one side and from plants physiology from other side. However, the variations in the concentrations of these elements in royal jelly were much lower than those observed for the associated honey. Results obtained in the frame of this study did not show strong a correlation between essential elements' concentrations and respective geographical region.

The potential toxic elements $\mathrm{As}, \mathrm{Cd}, \mathrm{Ni}$ and $\mathrm{Pb}$ could reach honey, pollen, propolis and wax through the air, water, plants and soil and be transported into the bee hive by the bees themselves. Kump et al. (1996) reported that bee tissue was more sensitive to such pollutants as $\mathrm{Pb}$ than bee honey. The elements $\mathrm{Pb}, \mathrm{Cd}, \mathrm{Co}$ and $\mathrm{Ni}$ have been widely studied as concentration levels in honey samples from different botanical and geographical origin (Chudzinska \& Baralkiewicz, 2010; Tuzen et al., 2007; Madejczyk \& Baralkiewicz, 2008; Vanhanen, Emmertz, \& Savage, 2011), and honey has been confirmed to be an indicator for the degree of anthropogenic impact on the environment. Because honey and pollen are the precursor substances for RJ production, toxic element content in RJ should also be relevant to their environmental concentrations. Results obtained in the present study undoubtedly showed almost equal and quite low content of toxic elements for all studied RJs. Fig. 4 presents the box plot diagram of the variations of these elements. Since all RJ samples were from unpolluted regions, the wide concentration ranges could be considered as a result of external contamination although at very low levels.

Up to now, international Maximum Residue Limit (MRL) levels have never been set for toxic elements content in RJ, but values of $0.1 \mathrm{mg} / \mathrm{kg}$ for $\mathrm{Cd}$ and $1 \mathrm{mg} / \mathrm{kg}$ for $\mathrm{Pb}$ in honey have been suggested for the EU (Bogdanov et al., 2007). The MRL levels for $\mathrm{Pb}$ and $\mathrm{Cd}$ in bee pollen are $0.5 \mathrm{mg} / \mathrm{kg}$ and $0.03 \mathrm{mg} / \mathrm{kg}$, respectively. (Campos et al., 2008). The average values for $\mathrm{Pb}$ and $\mathrm{Cd}$ in all studied Bulgarian RJs are lower than the 
above mentioned MRL.

The low toxic element content in RJs obtained in the present study might be explained with the "filtering" properties of the hypopharyngeal and mandibular glands of young worker honeybees. For this reason, $\mathrm{RJ}$ is the bee product which is least influenced by such contaminants as toxic elements.

Though the number of samples analyzed in this preliminary investigation was small, the results for the elemental composition of RJs were promising. The combination of ETAAS and ICP-OES measurements is suitable as a useful tool for the accurate quantification of trace and mineral elements in RJ samples. Insignificant differences were found for chemical element content in RJs independent of their geographical and botanical origin. These results confirmed once more the idea that trace and mineral element concentrations in RJ are under homeostatic control and RJ might be accepted as a form of lactation at the insect level.

\section{REFERENCES}

Bogdanov, S., Haldimann, M., Luginbühl, W., \& Gallmann, P. (2007). Minerals in honey: environmental, geographical and botanical aspects. Journal of Apicultural Research and Bee World, 46(4), 269-275.

Campos, M.G.R., Bogdanov, S., de Almeida-Muradian, L.B., Szczesna, T., Mancebo, Y., Frigerio, C., Ferreira, F. (2008). Pollen composition and standardization of analytical methods. Journal of Apicultural Research, 472), 154-161. http://dx.doi.org/10.1080/0021883 9.2008 .11101443

Chen, C., \& Chen, S.-Y. (1995). Changes in protein components and storage stability of royal jelly under various conditions. Food Chemistry, 54(2), 195200. DOl:10.1016/0308-8146(95)00031-D

Chudzinska, M, \& Baralkiewicz, D. (2010). Estimation of honey authenticity by multielements characteristics using inductively coupled plasma-mass spectrometry (ICP-MS) combined with chemometrics. Food and Chemical Toxicology, 48(1), 284-290. http://dx.doi.org/10.1016/j.fct.2009.10.011
Grout, R.A. (1992). The Hive and the Honey Bee. Revised edition, Dadant \& Sons, U.S.A.

IBM Corp. Released 2012. IBM SPSS Statistics for Windows, Version 21.0. Armonk, NY: IBM Corp.

ISO/DIS 12824:2016. Royal jelly - Specifications.

Ivanov, Ts., \& Chervenakova, I. (1985) Content of some macro-, oligo- and microelements in bee honey, royal jelly and pollen. Journal of Animal Science, 27,65-69.

Kim, J., \& Lee, J. (2010). Quantitative analysis of trans-10-hydroxy-2-decenoic acid in royal jelly products purchased in USA by high performance liquid chromatography. Journal of Apicultural Science, 54(1), 77-85.

Kump, P., Necemer, M., \& Šnajder, J. (1996). Determination of trace elements in bee honey, pollen and tissue by total reflection and radioisotope X-ray fluorescence spectrometry. Spectrochimica Acta Part B: Atomic Spectroscopy, 57(5), 499-507. D0l:10.1016/0584-8547(95)01435-7

Madejczyk, M., \& Baralkiewicz, D. (2008). Characterization of Polish rape and honeydew honey according to their mineral contents using ICP-MS and F-AAS/AES. Analytica Chimica Acta, 6171-2), 11-17. http://dx.doi.org/10.1016/j.aca.2008.01.038

Mureșan, C.I., Mãrghitaș, L.A., Dezmirean, D.S., Bobiș, O., Bonta, V., Zacharias, l., Mãrgãoan, R., Pașca, C. (2016). Quality parameters for commercialized royal jelly. Bulletin UASVM Animal Science and Biotechnologies, 73(1), 1-8. D0l:10.15835/buasvmcnasb:11630

Nation, J. L., \& Robinson, F. A. (1971). Concentration of Some Major and Trace Elements in Honeybees, Royal Jelly and Pollen, Determined by Atomic Absorption Spectrophotometry. Journal of Apicultural Research, 191), 35-43. http://dx.doi.org/10.1080/00 218839.1971.11099668

Piana, M. L., Belligoli, P., Persano Oddo, L., \& Piperno, S. (2006). Pollen analysis of royal jelly: Contribution to analytical methods and characterization. Apiacta, 
47,28-43.

Ricciardelli d'Albore, G., \& Battaglini Bernardini M. (1978). Origine géographique de la gelée royale. Apidologie, 9(1), 1-17. http://dx.doi.org/10.1051/apido:19780101

Sabatini, A. G., Marcazzan, G., Caboni, M. F., Bogdanov, S., Almeida-Muradian L. B. (2009). Quality and standardization of royal jelly. Journal of ApiProduct and ApiMedical Science, 7(1), 16-21. DOI: 10.3896/ IBRA.4.1.01.04

Serra Bonvehi, J. (1991). Composition en sels minéraux et en vitamines de la gelée royale.Bulletin Téchnique Apicole, 74(18), 13-20.

Stocker, A., Schramel, P., Kettrup, A., \& Bengsch, E. (2005). Trace and mineral elements in royal jelly and homeostatic effects. Journal of Trace Elements in Medicine and Biology, 192-3), 183-189. http://dx.doi. org/10.1016/j.jtemb.2005.08.004

Szczęsna, T. (2007). Concentration of selected elements in honeybee-collected pollen. Journal of Apicultural Science, 57(1), 5-13.

Terrab, A., Recamales, A. F., González-Miret, M. L, \& Heredia, F. J. (2005). Contribution to the study of avocado honeys by their mineral contents using inductively coupled plasma optical emission spectrometry. Food Chemistry, 92(2), 305-309. http:// dx.doi.org/10.1016/j.foodchem.2004.07.033

Tuzen, M., Silici, S., Mendil, D., \& Soylak, M. (2007). Trace element levels in honeys from different regions of Turkey. Food Chemistry, 103(2), 325-330. http://dx.doi.org/10.1016/j.foodchem.2006.07.053

Vanhanen, L. P, Emmertz, A, \& Savage, G. P. (2011). Mineral analysis of mono-floral New Zealand honey.Food Chemistry, 128(1), 236-240. http://dx.doi. org/10.1016/j.foodchem.2011.02.064 


\section{Quantification of Selected Trace and Mineral Elements in Royal Jelly from Bulgaria by ICP-OES and ETAAS \\ Elemental Composition of Bulgarian Royal Jelly}

\section{Supplementary material}

Optimized instrumental parameters for ICP-OES measurements

Table S1

\begin{tabular}{cc}
\hline Parameter & \\
\hline Generator power & $1100 \mathrm{~W}$ \\
Plasma gas flow rate & $13 \mathrm{~L} \mathrm{~min}^{-1}$ \\
Sheath gas flow rate & $0.2 \mathrm{~L} \mathrm{~min}^{-1}$ \\
Nebulizer & $0.8 \mathrm{~L} \mathrm{~min}^{-1}$ at 3 bars \\
Sample uptake & $0.8 \mathrm{~mL} \mathrm{~min}^{-1}$ \\
Type of nebulizer & Glass concentric \\
Type of spray chamber & Glass cyclonic \\
Argon humidifier & No \\
& Al 396.153; Ba 455.403; Ca 422.673; Cr 284.325; \\
Wavelengths, nm & Cu 324.754; Fe 259.940, K 766.490; Mg 279.806; \\
& Mn 257.610; Na 589.59; P 177.495; Sr 421. 552; Zn \\
& 213.856 \\
\hline
\end{tabular}

Table S2

The optimized HGA-600 temperature program for ETAAS measurements

\begin{tabular}{ccccc}
\hline Parameter & Drying & Pyrolysis & Atomization & Cleaning \\
\hline $\begin{array}{c}\text { Temperature } \\
\left({ }^{\circ} \mathrm{C}\right)\end{array}$ & 130 & Varies* & Varies* & Varies* \\
Ramp time $(\mathrm{s})$ & 10 & 20 & 0 & 1 \\
Hold time $(\mathrm{s})$ & 10 & 60 & 5 & 2 \\
Reading & & & $0 n$ & \\
$\begin{array}{c}\text { Ar flow mL } \\
\text { min }^{-1}\end{array}$ & 300 & 300 & 0 & 300 \\
\hline
\end{tabular}

*See Table 3S 
The optimized HGA-600 temperatures for $\mathrm{As}$, $\mathrm{Cd}$, Co, Ni and $\mathrm{Pb}$ meassurement

\begin{tabular}{cccc}
\hline Element & Pyrolysis $\left({ }^{\circ} \mathrm{C}\right)$ & Atomization $\left({ }^{\circ} \mathrm{C}\right)$ & Cleaning $\left({ }^{\circ} \mathrm{C}\right)$ \\
\hline $\mathrm{As}$ & 900 & 2200 & 2300 \\
$\mathrm{Cd}$ & $600^{\star}$ & 1400 & 1600 \\
$\mathrm{Co}$ & 1200 & 2300 & 2400 \\
$\mathrm{Ni}$ & 1000 & 2200 & 2300 \\
$\mathrm{~Pb}$ & 500 & 1500 & 1600 \\
\hline
\end{tabular}

*In the presence of Pd as modifier

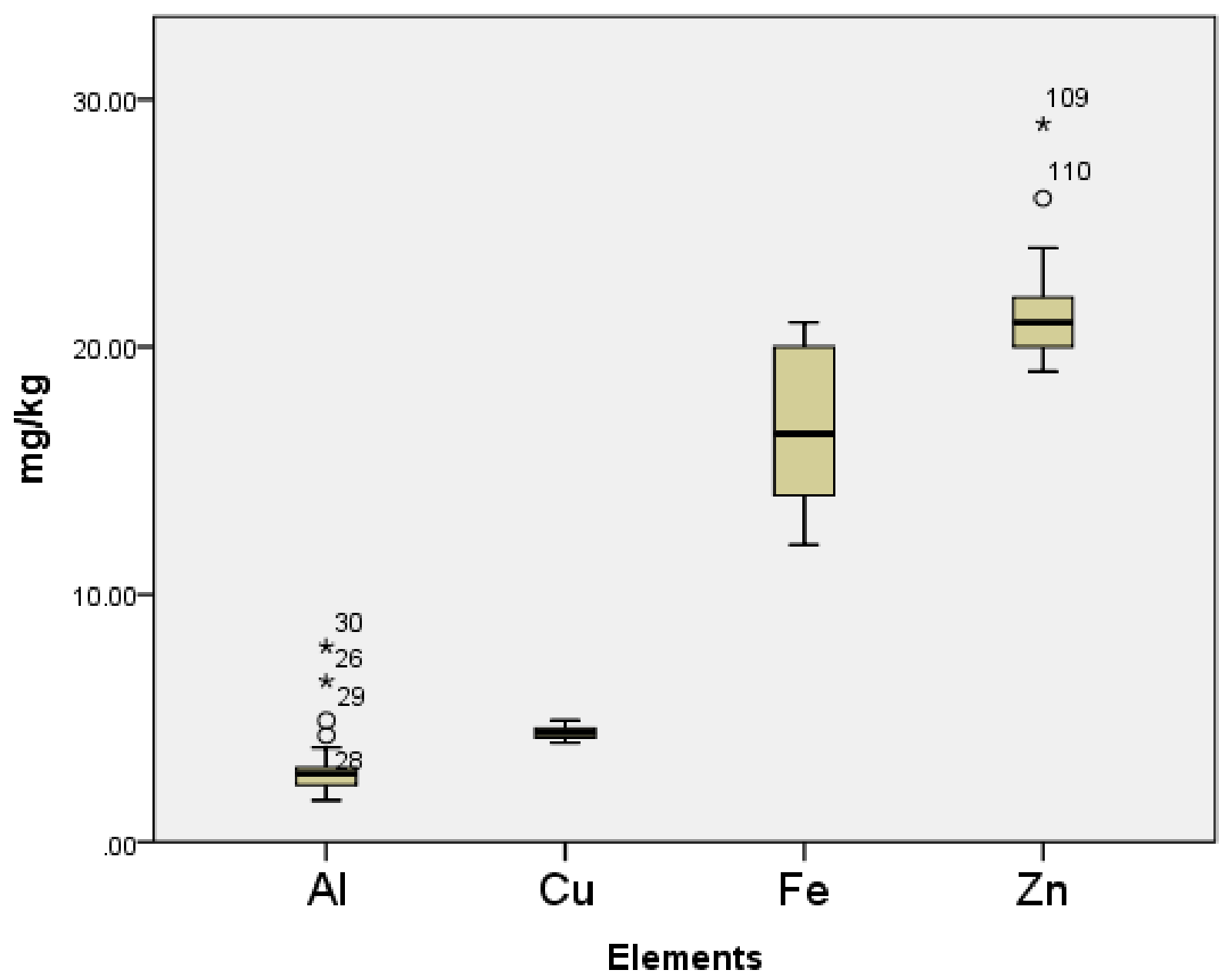

Fig. S1. Box plot diagram of the elements Al, Cu, Fe and $\mathrm{Zn}$ in RJ samples from Bulgaria. For each element minimum, maximum and median values are shown. 